\title{
Kazinol C from Broussonetia kazinoki activates AMP-activated protein kinase to induce antitumorigenic effects in HT-29 colon cancer cells
}

\author{
HAK-SU KIM ${ }^{1}$, JIHYUN LIM ${ }^{1}$, DA YEON LEE ${ }^{2}$, JAE-HA RYU ${ }^{2}$ and JONG-SEOK LIM ${ }^{1}$ \\ ${ }^{1}$ Department of Biological Science and the Research Center for Women's Diseases; ${ }^{2}$ Research Center for Cell Fate Control \\ and College of Pharmacy, Sookmyung Women's University, Yongsan-Gu, Seoul 140-742, Republic of Korea
}

Received May 15, 2014; Accepted July 21, 2014

DOI: $10.3892 /$ or.2014.3601

\begin{abstract}
Kazinol C is a 1,3-diphenylpropane, obtained from Broussonetia kazinoki, that has been employed in folk medicine as an edema suppressant. It exerts beneficial effects in oxidative stress-related diseases, such as cancer. However, the molecular mechanism involved in the anticancer effects remains to be determined. AMP-activated protein kinase (AMPK) has emerged as a possible anticancer target molecule. The present study investigated the effect of kazinol $\mathrm{C}$ on AMPK activation as well as subsequent HT-29 colon cancer cell viability, apoptosis and migration. Kazinol C markedly induced AMPK phosphorylation and significantly attenuated HT-29 colon cancer cell growth and viability. Compound C, as a well-known AMPK inhibitor, blocked the kazinol C-induced cell death, and stable transduction of dominant-negative (DN) AMPK in colon cancer cells also inhibited kazinol C-induced cell apoptosis. In addition, kazinol C inhibited HT-29 cell migration and anchorage-independent growth. AMPK inhibition using stable transduction with DN AMPK significantly abrogated the kazinol $\mathrm{C}$-induced inhibition of cancer cell migration. Thus, AMPK is a critical and novel regulator of kazinol C-mediated cancer cell apoptosis and inhibition of migration, suggesting that AMPK is a prime cancer target.
\end{abstract}

\section{Introduction}

AMP-activated protein kinase (AMPK) primarily functions as an energy sensor, and is a heterotrimer with a catalytic

Correspondence to: Professor Jong-Seok Lim, Department of Biological Science and the Research Center for Women's Diseases, Sookmyung Women's University, Hyochangwongil 52, Yongsan-Gu, Seoul 140-742, Republic of Korea

E-mail: jslim@sookmyung.ac.kr

Professor Jae-Ha Ryu, Research Center for Cell Fate Control and College of Pharmacy, Sookmyung Women's University, Hyochangwongil 52, Yongsan-Gu, Seoul 140-742, Republic of Korea E-mail: ryuha@sookmyung.ac.kr

Key words: kazinol C, AMP-activated protein kinase, apoptosis, migration, colon cancer subunit $(\alpha)$ and two regulatory subunits $(\beta$ and $\gamma)(1)$. The AMPK catalytic subunit is phosphorylated by the upstream kinases, liver kinase B1 (LKB1) and calmodulin-dependent protein kinase kinase $\beta$ (CaMKK $\beta)$ (2). Additionally, tumorsuppressor proteins, such as LKB1 (3), tuberous sclerosis complex 2 (TSC2) (4) and p53 (5), and oncoproteins, such as ERK and cyclooxygenase-2 (COX-2) (6), are involved in the AMPK signaling network and contribute to the regulation of cell proliferation and death. Consistent with this role, AMPK inhibits prosurvival growth pathways, mediates cell cycle checkpoints and regulates mitotic progression (7). Recent studies have identified a function for AMPK as a sensor of genomic stability, which is an important mechanism for the inhibition of tumorigenesis (8). These AMPK activities are essential to prevent carcinogenesis. AMPK also acts as a regulator of cell motility. In a previous study, using melanoma cells, it was shown that berberine-mediated AMPK activation inhibited melanoma cell migration via inhibition of the ERK and COX-2 signaling pathways (9). Moreover, the increased phosphorylation of cytoplasmic linker protein-170, which is an AMPK substrate, regulates cell migration via dynamic microtubule assembly, and the LKB1-AMPK-S6K axis inhibits breast cancer cell migration and invasion $(10,11)$.

Broussonetia kazinoki belongs to the family Moraceae and is distributed throughout Korea, Japan and China. The leaves, branches and fruits of this medicinal plant have been used in Chinese folk medicine as a diuretic, tonic and edema suppressant. Previous investigations have demonstrated that this plant exerts various beneficial effects, such as anti-oxidative (12), cytotoxic (13), anti-hyperglycemic (14) and tyrosinase inhibitory activities (15). Kazinol $\mathrm{C}$ is a 1,3-diphenyl propane isolated from Broussonetia kazinoki. It enhances antioxidant effects through Fyn inhibition and prevents arachidonic acid and iron-induced cell death through the activation of the LKB1-AMPK pathway (12). However, the beneficial effects of kazinol $\mathrm{C}$ in cancer development are poorly understood.

In the present study, we investigated whether kazinol $\mathrm{C}$ induces AMPK activation and whether this induction affects HT-29 colon cancer cell apoptosis and migration. Kazinol C increases AMPK activity, which is critical in kazinol C-induced cell apoptosis and inhibition of the metastatic potential of HT-29 colon cancer cells. 


\section{Materials and methods}

Materials. Dulbecco's modified Eagle's medium (DMEM), glucose-free DMEM, neomycin (G418) and fetal bovine serum (FBS) were obtained from Gibco-Invitrogen (Carlsbad, CA, USA). Propidium iodide (PI), 12-O-tetradecanoylphorbol-13acetate (TPA) and 3-[4,5-dimethylthiazol-2-yl]-2,5-diphenyl tetrazolium bromide (MTT) were obtained from Sigma-Aldrich (St. Louis, MO, USA). We obtained 5-aminoimidazole-4carboxamide-1- $\beta$-D-ribofuranoside (AICAR) and antibodies recognizing the phospho-specific forms of AMPK $\alpha-\mathrm{Thr}^{172}$ and ACC-Ser ${ }^{79}$ from Cell Signaling Technology (Boston, MA, USA). Antibodies against $\alpha$-actinin, poly (ADP-ribose) polymerase (PARP) and AMPKa were purchased from Santa Cruz Biotechnology, Inc. (Santa Cruz, CA, USA). Compound C was purchased from Calbiochem (San Diego, CA, USA).

Cell cultures. HT-29 colon cancer cells (ATCC, Manassas, VA, USA) were maintained in DMEM supplemented with $10 \%$ heat-inactivated FBS, $100 \mathrm{U} / \mathrm{ml}$ penicillin and $100 \mathrm{mg} / \mathrm{ml}$ streptomycin (Gibco-Invitrogen) at $37^{\circ} \mathrm{C}$ in a $5 \% \mathrm{CO}_{2}$ humidified incubator.

Kazinol C isolation. The air-dried root bark of Broussonetia kazinoki (voucher specimen no. SPH 07002) $(0.6 \mathrm{~kg}$ ) was extracted with ethanol. The extract $(51 \mathrm{~g})$ was fractionated into n-hexane, EtOAc, $\mathrm{CHCl}_{3}$ and $\mathrm{BuOH}$ soluble fractions. The EtOAc fraction $(31 \mathrm{~g})$ was subject to silica gel column chromatography followed by eluting with an $\mathrm{n}$-hexane/acetone gradient system (20:1 $\rightarrow 1: 10)$ and 11 fractions were collected as previously described (16). Fraction 7 was chromatographed using a silica gel column with $\mathrm{CHCl}_{3}: \mathrm{MeOH}(100: 1 \rightarrow 10: 1)$ to yield 6 subfractions. Sub-fraction 3 of fraction 7 was chromatographed on a RP-C18 column with a gradient $\mathrm{MeOH}(40 \rightarrow 100 \%)$ elution to yield kazinol C $(260 \mathrm{mg})$. The purity was confirmed by HPLC analyses and ${ }^{1} \mathrm{H}$-NMR spectrum. The chemical structure of kazinol $\mathrm{C}$ was elucidated by spectroscopic analyses and confirmed by comparison with previous studies (17).

Cell apoptosis and viability. Cell apoptosis was assessed using a fluorescence-activated cell sorter (FACS). In brief, the cells were treated with kazinol $\mathrm{C}$ for $24 \mathrm{~h}$. The cells were harvested by trypsinization and washed with phosphate-buffered saline (PBS). After fixation in $70 \%$ ethanol, the cells were resuspended in PBS containing $10 \mu \mathrm{g} / \mathrm{ml}$ PI. The fluorescence intensity was determined using a FACSCanto ${ }^{\mathrm{TM}}$ II flow cytometer (BD Biosciences, San Jose, CA, USA). Cell viability was assessed using the MTT assay. The cells were treated with $5 \mu \mathrm{g} / \mathrm{ml}$ MTT solution and incubated for $3 \mathrm{~h}$, and then dissolved in DMSO. The absorbance was measured at $570 \mathrm{~nm}$.

In vitro cell growth and soft agar colony formation assays. For the in vitro cell growth analysis, the cells were seeded in a 6-well plate and treated with $0-60 \mu \mathrm{M}$ of kazinol $\mathrm{C}$ for 24-48 $\mathrm{h}$. The cells were harvested and counted using the trypan blue exclusion test. To determine anchorage-independent cell growth, $1 \times 10^{3}$ HT- 29 cells were suspended in $1.5 \mathrm{ml}$ of the medium containing $0.3 \%$ agar, $10 \% \mathrm{FBS}$ and $15 \mu \mathrm{M}$ kazinol C, and the mixture was applied onto pre-solidified $0.5 \%$ agar $(1.5 \mathrm{ml})$ in 6-well plates. After incubation of two weeks, soft agar colonies were observed under a phase-contrast microscope and photographed.

Wound healing assay. The cells were seeded in 6-well plates and incubated for $12 \mathrm{~h}$ in starvation medium. The cellular monolayer was wounded with a sterile $200-\mu 1$ pipette tip and washed with starvation medium to remove detached cells from the plates. The cells were pretreated with $0-15 \mu \mathrm{M}$ kazinol $\mathrm{C}$ for $30 \mathrm{~min}$, and incubated in the presence or absence of $40 \mathrm{ng} / \mathrm{ml}$ TPA for $36 \mathrm{~h}$. The medium was replaced with PBS, and the cells were photographed using a phase-contrast microscope.

Determination of in vitro tumor cell migration. The in vitro migration and invasion assays were performed using a 24-well Transwell unit with polycarbonate filters with a $6.5 \mathrm{~mm}$ diameter and $8.0-\mu \mathrm{m}$ pore size (Corning Costar, Cambridge, MA, USA). For the invasion assay, the lower chamber of the Transwell was filled with DMEM plus 10\% FBS as a chemoattractant and the Transwell was assembled to serve as the intervening invasive barrier in a 24-well plate. The cells $\left(5 \times 10^{4}\right)$ were suspended in serum-free DMEM with $15 \mu \mathrm{M}$ kazinol C, added to the upper chamber of the Transwell and incubated for $48 \mathrm{~h}$ at $37^{\circ} \mathrm{C}$. The cells that attached to the upper surface of the filter were completely removed by wiping with a cotton swab, and the filters were stained with a $0.2 \%$ crystal violet $/ 20 \%$ methanol (w/v) solution.

Plasmid transfection. pcDNA3-AMPK dominant-negative (DN) form was prepared as previously described (18). The plasmid was transfected into HT-29 cells using PolyFect Transfection Reagent (Qiagen, Valencia, CA, USA) according to the manufacturer's instructions. Transfected cells were selected using complete medium containing $1 \mathrm{mg} / \mathrm{ml}$ neomycin.

Western blotting. For the whole-cell lysate preparation, the treated cells were lysed on ice in the PRO-PREP ${ }^{\mathrm{TM}}$ protein extraction solution (iNtRON Biotechnology, Seoul, Korea) for $30 \mathrm{~min}$ at $4^{\circ} \mathrm{C}$. The supernatant fractions were recovered by centrifugation $\left(14,000 \mathrm{x}\right.$ g for $20 \mathrm{~min}$ at $\left.4^{\circ} \mathrm{C}\right)$, and the protein concentration was determined using the Bradford protein assay. The samples were prepared with 2-mercaptoethanol and denatured by heating at $95^{\circ} \mathrm{C}$ for $3 \mathrm{~min}$. The proteins were separated on $8-12 \%$ polyacrylamide gels and transferred to nitrocellulose membranes. The membranes were blocked with $1 \%$ bovine serum albumin or $5 \%$ skim milk and hybridized with the primary antibody. Following hybridization with the HRP-conjugated secondary antibody, the protein bands were visualized using a chemiluminescence detection kit (Amersham Pharmacia Biotech, Piscataway, NJ, USA) and a LAS-3000 or LAS-4000 imaging system (Fujifilm Corporation, Tokyo, Japan). The western blotting band intensity was analyzed using Quantity One software (Bio-Rad Laboratories, Hercules, CA, USA).

Statistical analysis. The results are presented as the means \pm SD. The data were analyzed for statistical significance using GraphPad Prism 5 software (GraphPad Software, La Jolla, CA, USA). Significant differences were analyzed using one-way ANOVA followed by the Newman-Keuls multiple comparison tests $>3$ groups or the unpaired t-test for 
A

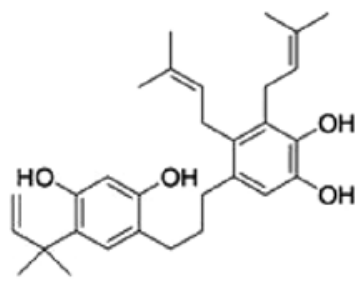

C

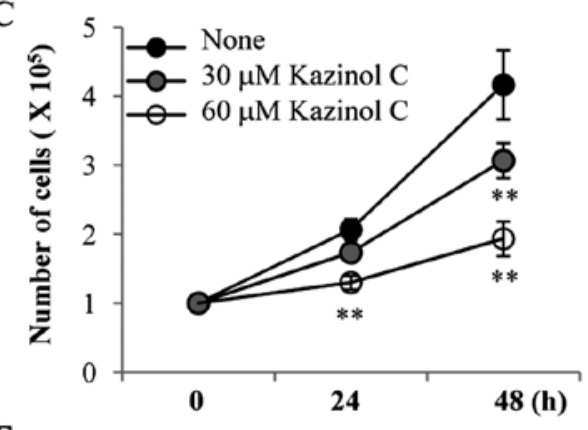

E

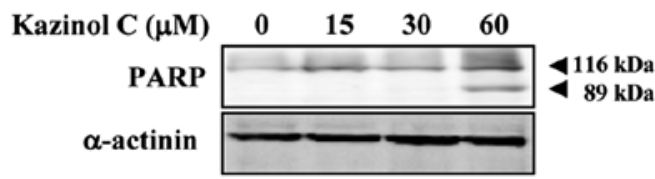

B

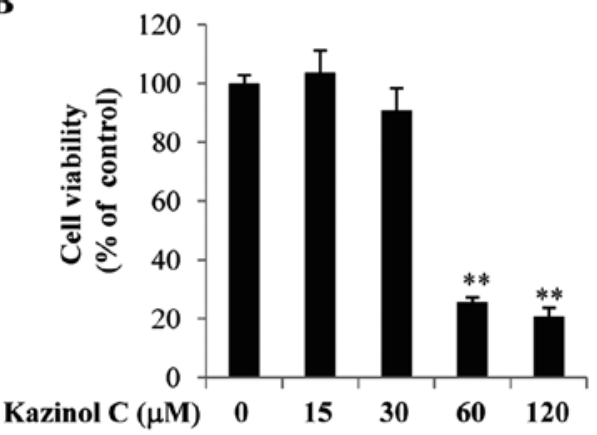

D

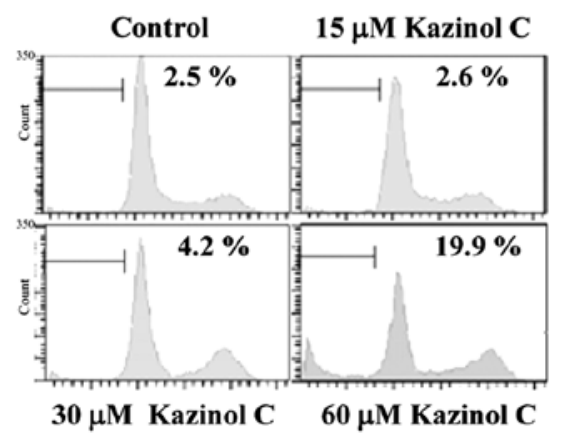

Figure 1. The effect of kazinol C on HT-29 colon cancer cell apoptosis. (A) The structure of kazinol C, a compound isolated from Broussonetia kazinoki. (B) HT-29 cells were seeded and treated with the indicated concentrations of kazinol C for $24 \mathrm{~h}$. Cell viability was estimated using the MTT assay. The data from four experiments are expressed as the means $\pm \mathrm{SD}\left({ }^{* *} \mathrm{P}<0.01\right)$. (C) The cells were treated with the indicated concentrations of kazinol $\mathrm{C}$ for $24-48 \mathrm{~h}$ and quantified. The data from three experiments are expressed as the means $\pm \operatorname{SD}\left({ }^{* *} \mathrm{P}<0.01\right)$. (D) The cells were treated with the indicated concentrations of kazinol $\mathrm{C}$ for $24 \mathrm{~h}$. The induction of apoptosis was measured by flow cytometry, and the percentage of sub-G1 cells is indicated. (E) The cells were treated with the indicated concentrations of kazinol $\mathrm{C}$ for $24 \mathrm{~h}$. Total cell extracts were prepared and subjected to western blot analysis using anti-PARP and anti- $\alpha$-actinin antibodies.

two groups. $\mathrm{P}<0.05$ was considered to indicate a statistically significant result.

\section{Results}

Kazinol C induces apoptosis in HT-29 colon cancer cells. Kazinol C is an active component of Broussonetia kazinoki. The kazinol $\mathrm{C}$ chemical structure used in the present study is shown in Fig. 1A. Kazinol C reportedly prevents cellular injury from reactive oxygen species (12). However, the anticancer effects of kazinol $\mathrm{C}$ remain unclear. In the present study, we first examined the effects of kazinol C on HT-29 colon cancer cell death. The cells maintained in complete medium were exposed to kazinol $\mathrm{C}$ for $24 \mathrm{~h}$. Cells exposed to low concentrations $(<30 \mu \mathrm{M})$ of kazinol $\mathrm{C}$ for $24 \mathrm{~h}$ exhibited no substantial increase in cell death, as assessed by the MTT assay (Fig. 1B). However, high concentrations (60-120 $\mu \mathrm{M})$ of kazinol C significantly increased HT-29 cell death. Additionally, treatment with 30-60 $\mu \mathrm{M}$ kazinol C for $48 \mathrm{~h}$ significantly reduced HT-29 cell growth; however, cell growth was not affected by treatment with $30 \mu \mathrm{M}$ kazinol $\mathrm{C}$ for $24 \mathrm{~h}$ (Fig. 1C). To verify whether kazinol $\mathrm{C}$ induces apoptosis, we performed FACS analysis of the sub-G1 DNA content. Low concentrations $(<30 \mu \mathrm{M})$ of kazinol C did not significantly affect HT-29 cell apoptosis at $24 \mathrm{~h}$, whereas $60 \mu \mathrm{M}$ kazinol C significantly induced apoptosis (Fig. 1D). This result was supported by PARP cleavage following treatment with $60 \mu \mathrm{M}$ kazinol C (Fig. 1E). Collectively, these results showed that kazinol C effectively induces HT-29 cell apoptosis.
Kazinol C increases AMPK activity in HT-29 colon cancer cells. AMPK activation results in apoptosis induction by modulating signaling pathways involved in cell proliferation and apoptosis (19). In our previous screening for natural compounds that act as AMPK activators, kazinol $\mathrm{C}$ was selected as a potent AMPK activator (data not shown). To investigate the effect of kazinol C on AMPK activity in HT-29 cells, we treated the cells with kazinol C in a time- and dose-dependent manner. Kazinol $\mathrm{C}$ markedly increased $\mathrm{Thr}^{172}$ phosphorylation in the catalytic subunit of AMPK and $\mathrm{Ser}^{79}$ phosphorylation in acetyl-CoA carboxylase (ACC), which is a well-characterized AMPK cellular substrate (Fig. 2A and B). These results suggested that kazinol $\mathrm{C}$ activates AMPK.

AMPK activation is critical for kazinol C-induced HT-29 colon cancer cell apoptosis. To examine the causal relationship between AMPK activation and kazinol C-induced cell death, the MTT assay was performed after HT-29 cells were pretreated with the AMPK inhibitor compound C or the AMPK activator AICAR. Compound C-mediated inhibition of AMPK activity markedly abrogated the kazinol C-induced cell death in a dose-dependent manner (Fig. 3A). By contrast, the AMPK activator AICAR did not significantly affect kazinol C-induced cell death. Of note, although the AICAR concentration did not induce cell death, AICAR increased AMPK activity at this concentration (Fig. 3A). Moreover, compound C inhibited kazinol C-induced apoptosis, as assessed by FACS analysis of the sub-G1 DNA content (Fig. 3B) or PARP cleavage (Fig. 3C). To confirm these results, we used a molecular approach to 


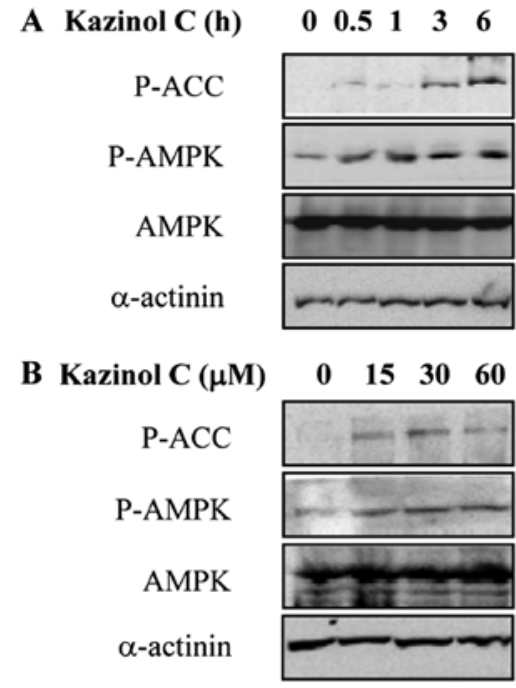

Figure 2. Kazinol C treatment increases AMPK activity. (A) HT-29 cells were treated with $60 \mu \mathrm{M}$ kazinol $\mathrm{C}$ for the indicated times. Total cell extracts were subjected to western blot analysis using specific antibodies against P-ACC, P-AMPK, AMPK and $\alpha$-actinin. (B) HT-29 cells were seeded and treated with indicated concentrations of kazinol $\mathrm{C}$ for $1 \mathrm{~h}$. Total cell extracts were subjected to western blot analysis using specific antibodies. AMPK, AMP-activated protein kinase; ACC, acetyl-CoA carboxylase.

regulate AMPK activity. Stable clones of HT-29 cells following transfection with pcDNA3 or AMPK-DN plasmids were established. We confirmed that AMPK activity was attenuated by the stable expression of the DN form of AMPK and that kazinol C-induced AMPK activation was markedly reduced by AMPK-DN expression (Fig. 4A). As demonstrated via FACS analysis of the sub-G1 DNA content, kazinol C effectively induced cell apoptosis and expression of the AMPK-DN form significantly abrogated kazinol C-induced apoptosis (Fig. 4B). These results suggested that kazinol $\mathrm{C}$ markedly increases HT-29 cell apoptosis through the activation of AMPK, which plays an important role in apoptosis induction.

Kazinol C inhibits HT-29 cell migration and anchorageindependent growth. Tumor metastasis is a multi-step process that includes migration, invasion, adhesion, proliferation and angiogenesis. To evaluate the effect of kazinol $\mathrm{C}$ on tumor metastatic activity, we performed in vitro migration and wound healing assays. As shown in Fig. 5A, 7.5-30 $\mu \mathrm{M}$ kazinol $\mathrm{C}$ did not significantly affect HT-29 cell growth at $24 \mathrm{~h}$. In HT-29 cells, kazinol C-treatment for $24 \mathrm{~h}$ significantly reduced wound healing (Fig. 5B). Similar results were observed with an in vitro migration assay (Fig. 5C). Given that TPA treatment typically stimulates colon cancer cell migration, we determined the effects of TPA on the kazinol C-induced inhibition of cell migration. Notably, TPA treatment increased wound healing and HT-29 cell migration, whereas kazinol C markedly abrogated TPA-induced wound healing and migration (Fig. 5B and C). We tested the ability of cells to form colonies in a semisolid medium as an indicator of metastatic potential. Untreated and TPA-treated HT-29 cells formed sizable colonies and increased proliferation in soft agar (Fig. 5D). However, kazinol C treatment significantly decreased basal and TPA-induced cell proliferation in soft agar. To examine the causal relationship between AMPK and kazinol C-induced inhibition of migra-
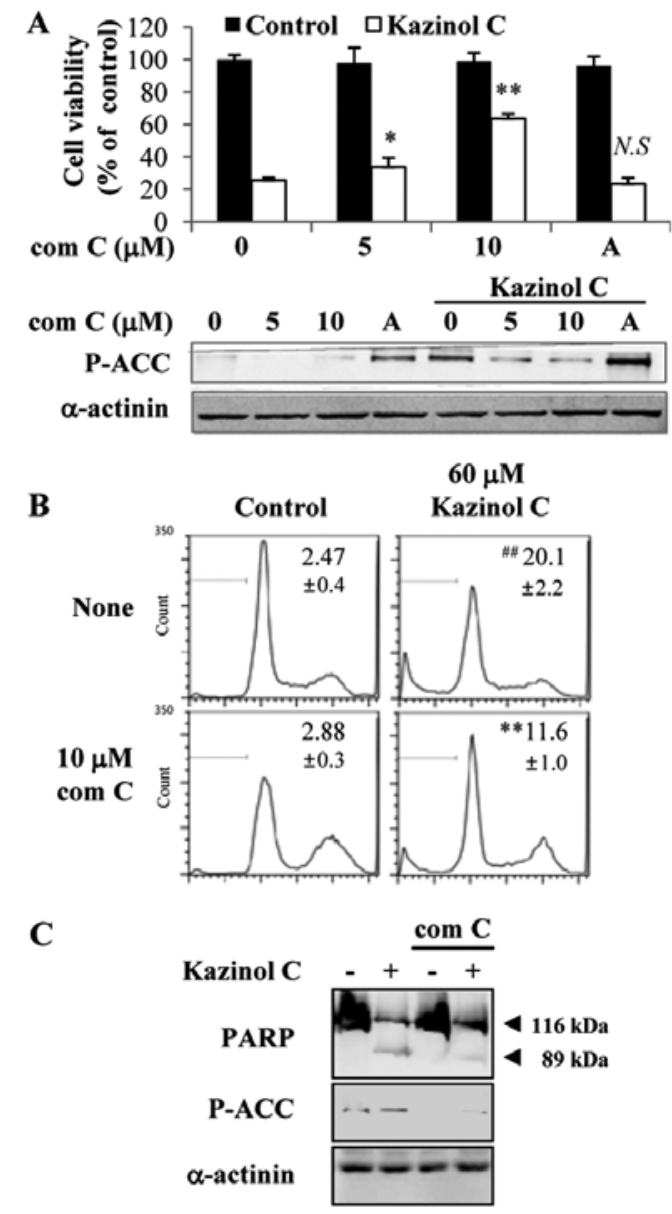

Figure 3. AMPK inhibition reduces kazinol C-induced apoptosis. (A) HT-29 cells were pretreated with the indicated concentrations of compound $\mathrm{C}$ (com C) or $300 \mu \mathrm{M}$ AICAR for 20 min and then treated with $60 \mu \mathrm{M}$ kazinol $\mathrm{C}$ for $24 \mathrm{~h}$. Cell viability was estimated using the MTT assay. Data from three experiments are presented as the means $\pm \mathrm{SD}$ (N.S, not significant and $\left.{ }^{* *} \mathrm{P}<0.01\right)$. For western blot analysis, the cells were pretreated with the indicated concentrations of compound $\mathrm{C}$ or $300 \mu \mathrm{M}$ AICAR for $20 \mathrm{~min}$ and then treated with $60 \mu \mathrm{M}$ kazinol $\mathrm{C}$ for $1 \mathrm{~h}$. (B) The cells were pretreated with $10 \mu \mathrm{M}$ compound $\mathrm{C}$ for $20 \mathrm{~min}$ and then treated with $60 \mu \mathrm{M}$ kazinol $\mathrm{C}$ for $24 \mathrm{~h}$. The apoptosis induction was analyzed by flow cytometry, and the percentage of sub-G1 cells is indicated. Data from three experiments are presented as the means $\pm \mathrm{SD}\left({ }^{\# \#} \mathrm{P}<0.01\right.$, compared with the control and ${ }^{* *} \mathrm{P}<0.01$, compared with kazinol $\mathrm{C}$ alone). (C) The cells pretreated with compound $\mathrm{C}$ were treated with $60 \mu \mathrm{M}$ kazinol $\mathrm{C}$ for $24 \mathrm{~h}$. Total cell extracts were subjected to western blot analysis using anti-PARP, anti-P-ACC and anti- $\alpha$-actinin antibodies. AMPK, AMP-activated protein kinase; ACC, acetyl-CoA carboxylase.

tion, we used a molecular approach to inhibit AMPK activity. AMPK inhibition via stable transfection with the AMPK-DN form significantly abrogated kazinol C-mediated inhibition of cancer cell migration (Fig. 6). Collectively, these results suggested that kazinol $\mathrm{C}$ inhibits the migration and anchorageindependent growth of HT-29 cells through AMPK activation.

\section{Discussion}

Colorectal cancer is the most common cancer and second leading cause of cancer-related mortality in the USA. Therefore, an attempt has been made to identify natural active compounds for the treatment of colorectal cancer. Compounds that induce apoptosis may have chemotherapeutic value given that a primary cancer characteristic is an imbalance of proliferation 
A

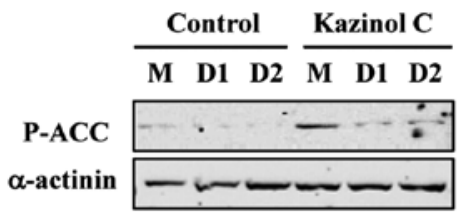

B

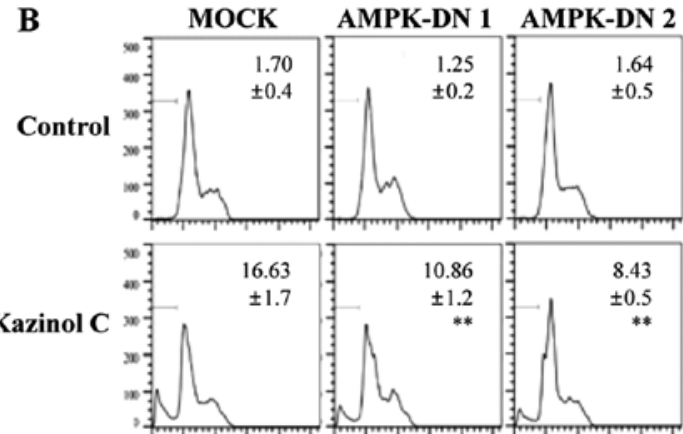

Figure 4. Expression of the AMPK-DN form abrogates kazinol C-induced apoptosis. (A) Stable clones of HT-29 cells were established following transfection with pcDNA3 (mock) or AMPK dominant-negative (DN) plasmids. These clones were treated with $60 \mu \mathrm{M}$ kazinol C for $1 \mathrm{~h}$, and total cell extracts were subjected to western blot analysis using anti-P-ACC and anti- $\alpha$-actinin antibodies. (B) These clones were treated with $60 \mu \mathrm{M}$ kazinol C for $24 \mathrm{~h}$. The apoptosis induction was measured by flow cytometry, and the percentage of sub-G1 cells is shown. Data from three experiments are presented as the means \pm SD $\left({ }^{* *} \mathrm{P}<0.01\right.$, compared with mock cells treated with kazinol C). AMPK, AMP-activated protein kinase; ACC, acetyl-CoA carboxylase.

A

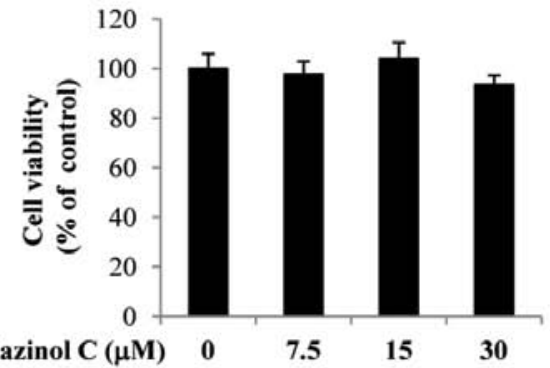

Control Kazinol C

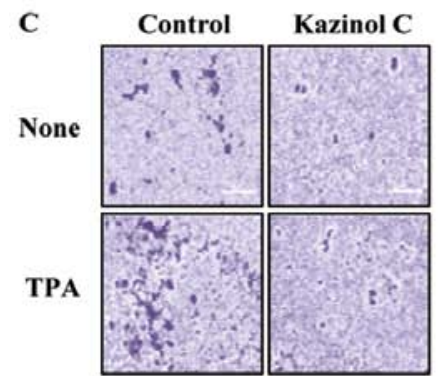

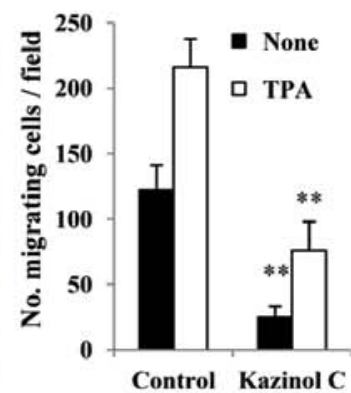

B

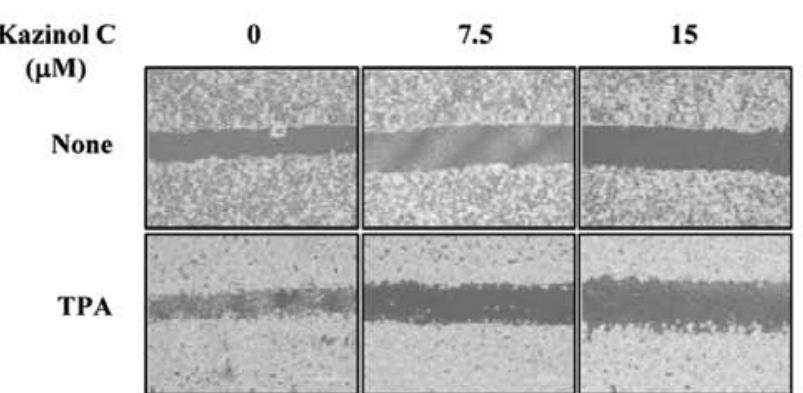

D
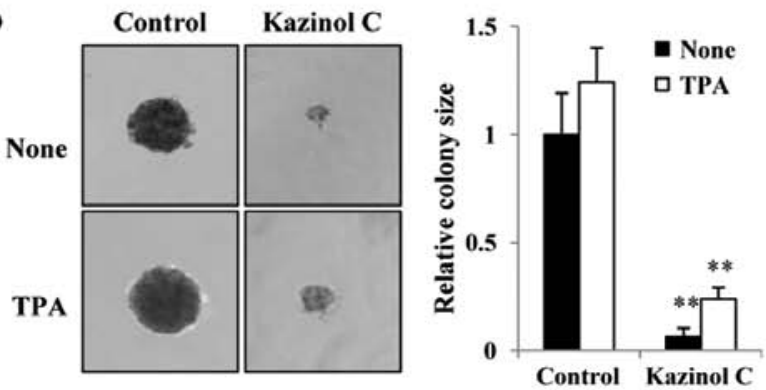

Figure 5. Kazinol C inhibits HT-29 cell migration and anchorage-independent growth. (A) HT-29 cells were treated with the indicated concentrations of kazinol C for $24 \mathrm{~h}$, and cell viability was estimated using the MTT assay. Data from three experiments are presented as the means \pm SD. (B) Cells were grown to confluence, and the plate was scratched with a pipette tip. The cells were pretreated with indicated concentrations of kazinol $\mathrm{C}$ for 30 min and then treated with $40 \mu \mathrm{g} / \mathrm{ml} \mathrm{TPA}$. After incubation for $24 \mathrm{~h}$, the plates were observed using a phase-contrast microscope. (C) A fixed number of cells were suspended in serum-free medium with $15 \mu \mathrm{M}$ kazinol $\mathrm{C}$ and added to the upper chamber of the Transwell, whereas the lower chamber was filled with medium containing $10 \%$ FBS. After incubation for $48 \mathrm{~h}$, the migrating cells were counted, and the results were presented as the mean number of migratory cells $\pm \mathrm{SD} / \mathrm{microscopic}$ field. (D) HT-29 cells $\left(1 \times 10^{3}\right)$ were suspended in $1.5 \mathrm{ml}$ of medium containing $0.3 \%$ agar, $10 \%$ FBS and $15 \mu \mathrm{M}$ kazinol C or $20 \mathrm{mg} / \mathrm{ml} \mathrm{TPA}$, and the mixture was applied onto pre-solidified $0.5 \%$ agar $(15 \mathrm{ml})$ with kazinol C or TPA in a 6-well culture plate. After incubation for 2 weeks, the diameter of 5-10 representative colonies was measured. TPA, 12-O-tetradecanoylphorbol-13-acetate.

and apoptosis. Kazinol $\mathrm{C}$ is an active component derived from Broussonetia kazinoki that exerts beneficial effects in oxidative stress-related diseases, such as cancer (12). However, the anticancer effects of kazinol $\mathrm{C}$ are poorly understood. The aim of this study was to establish a potential rationale for the clinical application of kazinol C, thus, the anticancer effect of kazinol C in HT-29 colon cancer cells was investigated. The present study focused on AMPK, which is the main molecule of the intracellular energy-sensing system. We found that kazinol C strongly induces AMPK phosphorylation and significantly attenuates cancer cell growth and viability. To examine the relationship between kazinol C-induced AMPK activation and cancer cell apoptosis, we suppressed AMPK activity using compound C or stable transfection of the AMPK-DN form. The inhibition of AMPK activity effectively blocks kazinol C-induced cell apoptosis. Kazinol C also inhibits cell migration, which regulates tumor metastasis and the anchorage-independent growth of HT-29 cells through increased AMPK activity. Thus, our data clearly demonstrate that kazinol $\mathrm{C}$ functions as an effective anticancer molecule in HT-29 cells.

AMPK is a novel therapeutic cancer target given that it serves as a pivotal role between cell survival and 


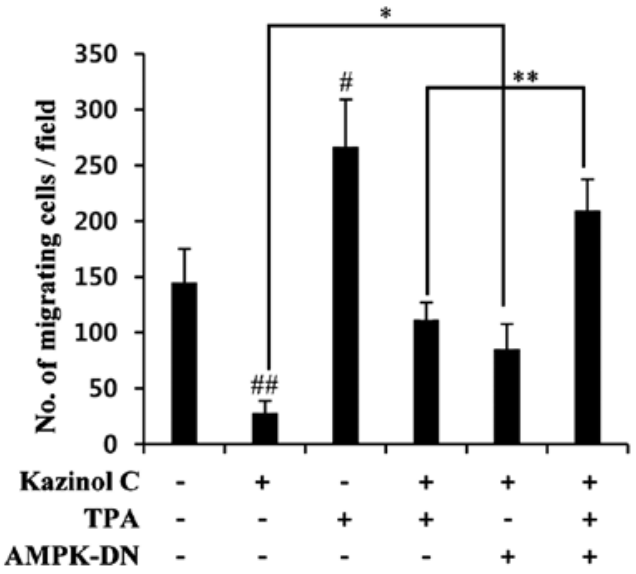

Figure 6. The effect of AMPK inhibition on the kazinol C-induced inhibition of cell migration. Cells that were selected after stable transfection with AMPK-DN plasmid were suspended in serum-free medium with $15 \mu \mathrm{M}$ kazinol C or $40 \mu \mathrm{g} / \mathrm{ml}$ TPA and added to the upper chamber of the Transwell. The lower chamber was filled with medium containing 10\% FBS. After incubation for $48 \mathrm{~h}$, the migrating cells were counted, and the results were presented as the mean number of migratory cells $\pm \mathrm{SD} /$ microscopic field. AMPK, AMP-activated protein kinase; DN, dominant-negative; TPA, 12- $O$-tetradecanoylphorbol-13-acetate; FBS, fetal bovine serum.

apoptosis (19). In previous studies, AMPK was strongly activated during the early stages of primary brain tumor formation in rat and glucose deprivation- or hypoxia-induced AMPK activation was shown to induce cell survival in various cell types (20-22). However, pharmacological studies have suggested the tumor-suppressor functions of AMPK. For example, metformin is a potent AMPK activator. Diabetes patients administered metformin exhibit a lower risk of colon cancer development compared with non-metformin users (23). In addition, aspirin, a synthetic non-steroidal anti-inflammatory drug (NSAID), has also been shown to reduce colon cancer development through the direct activation of AMPK $(24,25)$. Inflammation is a key factor involved in colorectal tumor progression as supported by increasing data, and AMPK can function as an anti-inflammatory molecule via COX-2 or NF- $\mathrm{kB}$ inhibition $(6,26)$. Furthermore, quercetin, berberine and resveratrol reportedly exert anticancer effects via AMPK activation (27-29). Although the role of AMPK in cancer cells is controversial, pharmacological studies have indicated that pharmacological induction of AMPK activity results in anticancer effects. Consequently, the identification of AMPK activators is a promising strategy for developing novel therapeutic drugs for the treatment of colon cancer.

AMPK also regulates cell motility. For example, CaMKK $\beta$-AMPK activation by lysophosphatidic acid or androgen increases ovarian and prostate cancer cell migration, respectively $(30,31)$. AMPK activation also contributes to transendothelial lymphocyte and endothelial cell migration $(32,33)$. By contrast, berberine-mediated AMPK activation inhibits melanoma and colon cancer cell migration $(9,34)$. Adiponectininduced LKB1-AMPK activity inhibits breast cancer cell migration through inhibition of the mTor-S6K pathway (11). Moreover, compound $\mathrm{C}$ inhibits vascular smooth muscle cell (SMC) migration in an AMPK-independent manner and AICAR also inhibits SMC migration (35). Accordingly, the role of AMPK in cell migration may be dependent on the type of stimulus or cell line. In the present study, kazinol $\mathrm{C}$ rapidly increased AMPK phosphorylation and inhibits TPA-induced cell migration. The inhibition of AMPK activity via transfection of the AMPK-DN form abrogates TPA-induced cell migration. Therefore, we hypothesize that kazinol C-mediated AMPK activation is a negative regulator of HT-29 cell migration. In addition, cancer cell growth in semisolid medium is an indicator of metastatic potential. Kazinol C significantly inhibits anchorage-independent HT-29 cell growth, and this result supports our hypothesis that kazinol C-induced AMPK activity may be associated with antimetastatic effects.

In conclusion, our data have identified a significant role of kazinol C-induced AMPK activation in the induction of HT-29 cell apoptosis. In addition, kazinol C inhibits migration and anchorage-independent growth of HT-29 cells. AMPK inhibition via stable transfection with the AMPK-DN form significantly abrogates the kazinol C-induced inhibition of cancer cell migration. Furthermore, the present study suggests that AMPK is a critical and novel regulator of kazinol C-induced cancer cell apoptosis and inhibition of migration, suggesting that AMPK is a prime cancer target.

\section{Acknowledgements}

This study was supported by the National Research Foundation of Korea (NRF) grants (Nos. 2011-0030074 and 2011-0011011) funded by the Korean government (Ministry of Science, ICT and Future Planning).

\section{References}

1. Hardie DG, Carling D and Carlson M: The AMP-activated/SNF1 protein kinase subfamily: metabolic sensors of the eukaryotic cell? Annu Rev Biochem 67: 821-855, 1998.

2. Hardie DG and Alessi DR: LKB1 and AMPK and the cancermetabolism link - ten years after. BMC Biol 11: 36, 2013.

3. Shackelford DB and Shaw RJ: The LKB1-AMPK pathway: metabolism and growth control in tumour suppression. Nat Rev Cancer 9: 563-575, 2009.

4. Inoki $\mathrm{K}$, Ouyang $\mathrm{H}$, Zhu T, Lindvall $\mathrm{C}$, Wang $\mathrm{Y}$, Zhang $\mathrm{X}$, Yang Q, Bennett C, Harada Y, Stankunas K, Wang CY, He X, MacDougald OA, You M, Williams BO and Guan KL: TSC2 integrates Wnt and energy signals via a coordinated phosphorylation by AMPK and GSK3 to regulate cell growth. Cell 126: 955-968, 2006.

5. Jones RG, Plas DR, Kubek S, Buzzai M, Mu J, Xu Y, Birnbaum MJ and Thompson CB: AMP-activated protein kinase induces a p53-dependent metabolic checkpoint. Mol Cell 18: 283-293, 2005.

6. Hwang JT, Kim YM, Surh YJ, Baik HW, Lee SK, Ha J and Park OJ: Selenium regulates cyclooxygenase-2 and extracellular signal-regulated kinase signaling pathways by activating AMP-activated protein kinase in colon cancer cells. Cancer Res 66: 10057-10063, 2006.

7. Mihaylova MM and Shaw RJ: The AMPK signalling pathway coordinates cell growth, autophagy and metabolism. Nat Cell Biol 13: 1016-1023, 2011.

8. Sanli T, Steinberg GR, Singh G and Tsakiridis T: AMP-activated protein kinase (AMPK) beyond metabolism: a novel genomic stress sensor participating in the DNA damage response pathway. Cancer Biol Ther 15: 156-169, 2014.

9. Kim HS, Kim MJ, Kim EJ, Yang Y, Lee MS and Lim JS: Berberineinduced AMPK activation inhibits the metastatic potential of melanoma cells via reduction of ERK activity and COX-2 protein expression. Biochem Pharmacol 83: 385-394, 2012.

10. Nakano A, Kato H, Watanabe T, Min KD, Yamazaki S, Asano Y, Seguchi O, Higo S, Shintani Y, Asanuma H, Asakura M, Minamino T, Kaibuchi K, Mochizuki N, Kitakaze $\mathrm{M}$ and Takashima S: AMPK controls the speed of microtubule polymerization and directional cell migration through CLIP-170 phosphorylation. Nat Cell Biol 12: 583-590, 2010. 
11. Taliaferro-Smith L, Nagalingam A, Zhong D, Zhou W, Saxena NK and Sharma D: LKB1 is required for adiponectinmediated modulation of AMPK-S6K axis and inhibition of migration and invasion of breast cancer cells. Oncogene 28: 2621-2633, 2009.

12. Kim AY, Lee CG, Lee da Y, Li H, Jeon R, Ryu JH and Kim SG: Enhanced antioxidant effect of prenylated polyphenols as Fyn inhibitor. Free Radic Biol Med 53: 1198-1208, 2012.

13. Ko HH, Yen MH, Wu RR, Won SJ and Lin CN: Cytotoxic isoprenylated flavans of Broussonetia kazinoki. J Nat Prod 62: 164-166, 1999.

14. Cha JY, Kim YT, Kim HS and Cho YS: Antihyperglycemic effect of stem bark powder from paper mulberry (Broussonetia kazinoki Sieb.) in type 2 diabetic Otsuka Long-Evans Tokushima fatty rats. J Med Food 11: 499-505, 2008

15. Baek YS, Ryu YB, Curtis-Long MJ, Ha TJ, Rengasamy R, Yang MS and Park KH: Tyrosinase inhibitory effects of 1,3-diphenylpropanes from Broussonetia kazinoki. Bioorg Med Chem 17: 35-41, 2009

16. Lee DY, Kim DH, Lee HJ, Lee Y, Ryu KH, Jung BI, Song YS and Ryu JH: New estrogenic compounds isolated from Broussonetia kazinoki. Bioorg Med Chem Lett 20: 3764-3767, 2010.

17. Ikuta J,Hano Y, Nomura T, Kawakami Y and Sato T: Components of Broussonetia kazinoki SIEB. I. Structures of two new isoprenylated flavans and five new isoprenylated 1,3-diphenylpropane derivatives. Chem Pharm Bull 34: 1968-1979, 1986.

18. Woods A, Azzout-Marniche D, Foretz M,Stein SC,Lemarchand P, Ferré P, Foufelle $\mathrm{F}$ and Carling D: Characterization of the role of AMP-activated protein kinase in the regulation of glucose-activated gene expression using constitutively active and dominant negative forms of the kinase. Mol Cell Biol 20: 6704-6711, 2000.

19. Wang W and Guan KL: AMP-activated protein kinase and cancer. Acta Physiol 196: 55-63, 2009.

20. Jang T, Calaoagan JM, Kwon E, Samuelsson S, Recht L and Laderoute KR: 5'-AMP-activated protein kinase activity is elevated early during primary brain tumor development in the rat. Int J Cancer 128: 2230-2239, 2011.

21. Yun H, Kim HS, Lee S, Kang I, Kim SS, Choe W and Ha J: AMP kinase signaling determines whether c-Jun N-terminal kinase promotes survival or apoptosis during glucose deprivation. Carcinogenesis 30: 529-537, 2009.

22. Kim HS, Wannatung T, Lee S, Yang WK, Chung SH, Lim JS, Choe W, Kang I, Kim SS and Ha J: Quercetin enhances hypoxiamediated apoptosis via direct inhibition of AMPK activity in HCT116 colon cancer. Apoptosis 17: 938-949, 2012.

23. Tseng CH: Diabetes, metformin use, and colon cancer: a population-based cohort study in Taiwan. Eur J Endocrinol 167: 409-416, 2012

24. Din FV, Valanciute A, Houde VP, Zibrova D, Green KA, Sakamoto K, Alessi DR and Dunlop MG: Aspirin inhibits mTOR signaling, activates AMP-activated protein kinase, and induces autophagy in colorectal cancer cells. Gastroenterology 142 1504-1515.e3, 2012.
25. Hawley SA, Fullerton MD, Ross FA, Schertzer JD, Chevtzoff C, Walker KJ, Peggie MW, Zibrova D, Green KA, Mustard KJ, Kemp BE, Sakamoto K, Steinberg GR and Hardie DG: The ancient drug salicylate directly activates AMP-activated protein kinase. Science 336: 918-922, 2012.

26. O'Neill LA and Hardie DG: Metabolism of inflammation limited by AMPK and pseudo-starvation. Nature 493: 346-355, 2013.

27. Lee YK and Park OJ: Regulation of mutual inhibitory activities between AMPK and Akt with quercetin in MCF-7 breast cancer cells. Oncol Rep 24: 1493-1497, 2010.

28. Yang $X$ and Huang N: Berberine induces selective apoptosis through the AMPK-mediated mitochondrial/caspase pathway in hepatocellular carcinoma. Mol Med Rep 8: 505-510, 2013.

29. Puissant A, Robert G, Fenouille N, Luciano F, Cassuto JP, Raynaud S and Auberger P: Resveratrol promotes autophagic cell death in chronic myelogenous leukemia cells via JNK-mediated p62/SQSTM1 expression and AMPK activation. Cancer Res 70: 1042-1052, 2010

30. Kim EK, Park JM, Lim S, Choi JW, Kim HS, Seok H, Seo JK, Oh K, Lee DS, Kim KT, Ryu SH and Suh PG: Activation of AMP-activated protein kinase is essential for lysophosphatidic acid-induced cell migration in ovarian cancer cells. J Biol Chem 286: 24036-24045, 2011.

31. Frigo DE, Howe MK, Wittmann BM, Brunner AM, Cushman I, Wang Q, Brown M, Means AR and McDonnell DP: CaM kinase kinase $\beta$-mediated activation of the growth regulatory kinase AMPK is required for androgen-dependent migration of prostate cancer cells. Cancer Res 71: 528-537, 2011.

32. Ouchi N, Kobayashi H, Kihara S, Kumada M, Sato K, Inoue T, Funahashi T and Walsh K: Adiponectin stimulates angiogenesis by promoting cross-talk between AMP-activated protein kinase and Akt signaling in endothelial cells. J Biol Chem 279: 1304-1309, 2004.

33. Martinelli R, Gegg M, Longbottom R, Adamson P, Turowski P and Greenwood J: ICAM-1-mediated endothelial nitric oxide synthase activation via calcium and AMP-activated protein kinase is required for transendothelial lymphocyte migration. Mol Biol Cell 20: 995-1005, 2009.

34. Park JJ, Seo SM, Kim EJ, Lee YJ, Ko YG, Ha J and Lee M: Berberine inhibits human colon cancer cell migration via AMP-activated protein kinase-mediated downregulation of integrin $\beta 1$ signaling. Biochem Biophys Res Commun 426: 461-467, 2012.

35. Peyton KJ, Yu Y, Yates B, Shebib AR, Liu XM, Wang H and Durante W: Compound C inhibits vascular smooth muscle cell proliferation and migration in an AMP-activated protein kinase-independent fashion. J Pharmacol Exp Ther 338: 476-484, 2011 